\title{
Soil Carbon and Structural Quality in Crop Rotations under No-tillage System
}

\author{
Lutécia Beatriz dos Santos Canalli ${ }^{1^{*}}$ \\ https://orcid.org/0000-0003-0821-8584 \\ Josiane Bürkner dos Santos ${ }^{1}$ \\ https://orcid.org/0000-0003-1252-869X \\ Dácio Antônio Benassi ${ }^{1}$ \\ https://orcid.org/0000-0002-6795-8999 \\ André Luiz Oliveira de Francisco ${ }^{1}$ \\ https://orcid.org/0000-0001-6458-8251
}

\author{
Caetano Benassi ${ }^{2}$ \\ https://orcid.org/0000-0002-6803-4157
}

Adriane Novakowski de Aguiar ${ }^{2}$

https://orcid.org/0000-0003-1970-5310

Elielson Cordeiro ${ }^{3}$

https://orcid.org/0000-0001-8052-4864

Renan Stanislavski Mendes ${ }^{3}$

https://orcid.org/0000-0002-2771-9221

1Paraná Agronomic Institute (IAPAR), Ponta Grossa, Paraná, Brazil; ${ }^{2}$ State University of Ponta Grossa (UEPG), Ponta Grossa, Paraná, Brazil; ${ }^{3}$ Higher Education Center of the Campos Gerais (CESCAGE), Agronomy/Scientific Initiation Program of IAPAR, Ponta Grossa, Paraná, Brazil.

Received: 2019.10.08; Accepted: 2020.04.09.

*Correspondence: e-mail: lutecia@iapar.br; Tel.: +55 (42) 3219-9712, IAPAR

\section{HIGHLIGHTS}

- Crop rotations did not influence the distribution of aggregate classes.

- Crop rotations did not alter the soil aggregation indexes.

- Carbon content in the soil aggregates classes did not differ among crop rotations.

Abstract: The no-tillage system associated with crops rotation affects the dynamics of soil organic matter, influencing the formation, reorganization and stabilization of aggregates and the carbon content (C) into soil aggregates. The aim of this study was to evaluate the effect of crop rotations under no-tillage system on $\mathrm{C}$ content and soil aggregation. The experiment was conducted at the Paraná Agronomic Institute in Ponta Grossa, PR, Brazil. The treatments consisted of six crop rotations, in a 3-year cycle, arranged in a randomized block design with four replications. Soil samples were collected at layers of $0-5,5-10$ and $10-20 \mathrm{~cm}$. The aggregate classification was determined by the wet sieving methodology, and the Weighted Mean Diameter (WMD), Geometric Mean Diameter (GMD) and Aggregate Stability Index (ASI) were calculated. The C content in the aggregates was determined by wet oxidation. The results were submitted to analysis of variance and Tukey test at $5 \%$ probability. There was no difference among crop rotations for aggregate classes and aggregation indexes, but were higher in surface, decreasing in depth. The carbon content in the aggregates did not differ among crop rotations, but presented stratification in the soil profile, decreasing in depth. The cycle of three years with crop rotation was insufficient to express possible changes in soil $\mathrm{C}$ content and aggregation.

Keywords: soil aggregate stability; organic matter; soil management; cover crops. 


\section{INTRODUCTION}

The no-tillage system associated with crop rotation affects soil organic matter dynamics, influencing the formation, reorganization and stabilization of soil aggregates, and the soil carbon content (C) into aggregates. Crops rotation provides improvements in soil quality through the maintenance and or increase of organic matter, biopores creation and greater soil structure [1].

Among the benefits of no-tillage system for the stability of the productive system we can highlight the increase of soil organic matter (SOM), reduction of mineralization rates, greater soil structure and aggregation, reduction of erosive potential, increase of diversity and biological activity [2].

The success of no-tillage system in tropical and subtropical regions has been associated with the use of plant species with high residue persistence on the soil, as high humidity and temperature conditions accelerate the decomposition of crop residues [3]. Therefore, the continuous and high input of plant residues is necessary to maintain soil cover and its positive effects for increasing organic matter and improving soil structure, among other benefits.

Soil organic matter (SOM) is formed mainly from the decomposition of residues of plant and animal origin, as well as products metabolized by microorganisms and compounds exuded by the root system of plants. These binding agents are essential for aggregate formation and stabilization. Many areas have difficulty maintaining soil organic matter when crops rotation is not done correctly [4]. There is a constant search for species that presents high biomass production capacity for insert in crop rotations, because the input of high amount of vegetal residues to the soil is fundamental for the success of No-tillage system [5]. Evaluating the effect of crop rotations on soil structural stability,[6] found that maize residues promoted greater aggregation in both surface and subsurface soil compared to soybean residues, resulting in less soil sediments loss in conventional system and no tillage.

Studying physical changes in the soil using different cover crops, [7] found that the use of these associated with the no-tillage system promoted positive changes in the superficial layer of the soil, with the increase of aggregate stability, mainly with Poaceae, as sorghum cover, presenting the best soil aggregation indexes, highlighting the microporosity, which presented higher increase than the other physical attributes. Evaluating different management systems, [8] concluded that no-tillage system associated with crops rotation for long-term, mainly including crops of dense root system, is able to recover the aggregation and carbon stock of degraded soils. The use of Poaceae species changes physical and chemical in the soil [9], promoting increases in the stability of aggregates and soil macroporosity, being important for the structural recovery of degraded soils.

The residues left by the plant species in the no-tillage system contribute to the increase of SOM, which is responsible by the addition of carbon in the soil [2] and, according to [10], the $C$ stratification ratio in the soil profile is a sensitive indicator for assessing the total and particulate organic carbon sequestration rate in the soil aggregates managed under No-till.

Stability of soil aggregates and soil organic matter are closely correlated, and aggregation status and organic carbon content are attributes that can be used to indicate soil quality [11]. Therefore, studying changes in soil aggregation and structure becomes important to assist in the implementation of management systems aimed at maintaining and / or restoring soil productive potential [12].

The objective of this study was to evaluate the influence of crop rotations under no-tillage system on carbon content and soil structure quality.

\section{MATERIAL AND METHODS}

The present study was conducted at the Experimental Station of the Paraná Agronomic Institute (IAPAR), in Ponta Grossa, Paraná state, Brazil, geographically located at 2507'30"S latitude and 500' $33^{\prime \prime} \mathrm{W}$ longitude, with an approximate altitude of $922 \mathrm{~m}$.

The soil at the experiment site was classified as typical dystrophic Oxisol (Rhodic Hapludox), with 14\% loam, $28 \%$ clay, $58 \%$ sandy texture, moderate A horizon [13], with slope of $7 \%$.

The climate of the region, according to Köppen classification, is Cfb, subtropical humid, mesothermal, with average annual temperature of $18 \stackrel{\circ}{\circ} \mathrm{C}$ and average annual rainfall of $1550 \mathrm{~mm}$ [14].

The experiment was implemented in April 2014 in an area that had been conducted under no-tillage system for four years, where in the winter black oat was sown for grazing animals and in the summer, alternately, maize and soybeans were cultivated. 
The experimental design was randomized blocks with six treatments and four replications. The plots dimension was 30 meters long by 10 meters wide.

The treatments consisted of one crops succession and, five crops rotations (six treatments), under notillage system, in a three-year cycle, as shown in Table1. The arrangement of the crops in each treatment was: 1) Succession (Crops succession) - consisted of wheat (Triticum aestivum) in the winters and soybean (Glycine max) in the summers, continuously, and represents the most common production system in the region; 2) Rotation I (Farmer crops rotation) - is characterized by the inclusion of maize (Zea mays) each two years of soybean, and before of maize, black oats (Avena strigosa) is sown for soil cover, being this rotation used by farmers that already realize the importance of including other crops to seek more equilibrium in the production system, but it is still incipient as a diversified crops rotation; 3 ) Rotation II (Cash crops rotation) consisted of cash crops as wheat and soybean, canola (Brassica napus) and maize, barley (Hordeum vulgare) and soybean, grown in the winter and summer, respectively, and was proposed to promote soil benefits through crops diversity without compromising the income return in the winter and summer; 4) Rotation III (Phytomass crops rotation) - consisted of the consortium among black oats + rye (Secale cereale) + hairy vetch (Vicia villosa) in the winter, beans(Phaseolus vulgaris) in the summer and Sorghum (Sorghum bicolor) in summer/autumn, after black oats + hairy vetch + forage turnip(Raphanus sativus) in the winter, maize in the summer, and after, triticale (Triticosecale rimpaul) + black oats + rye in the winter and soybean in the summer, and was proposed to intensify biomass production to increase organic matter and improving soil attributes (chemical, physical and biological), besides of nitrogen input provided by Fabaceae and longer soil protection by the high yield of Poaceae phytomass; 5) Rotation IV (cash and phytomass crops rotation) consisted of a consortium between blue lupine (Lupinus angustifolius) + black oats for soil cover and nitrogen fixation, aiming to favor maize in the summer, after white oats (Avena sativa) in the winter followed by beans in the summer and forage turnip in summer/autumn, and after, triticale in the winter and soybean in the summer; 6) Rotation V (consortium of Poaceae in the winter) - consisted of a consortium between black oat + ryegrass (Lolium multiflorum) in the winter, and soybean or maize, alternately, in the summers.

Crop management (planting season and spacing, sowing density, fertilization, pest control, diseases and weeds) was performed according to technical recommendations for each crop.

Table 1. Treatments composed by crop rotations in a three-year cycle, IAPAR, Ponta Grossa, Paraná State

\begin{tabular}{|c|c|c|c|c|c|c|}
\hline \multirow{2}{*}{ Treatments* } & \multicolumn{2}{|c|}{ Season $2014 / 15$} & \multicolumn{2}{|c|}{ Season $2015 / 16$} & \multicolumn{2}{|c|}{ Season $2016 / 17$} \\
\hline & Winter & Summer & Winter & Summer & Winter & Summer \\
\hline Succession & Wheat & Soybean & Wheat & Soybean & Wheat & Soybean \\
\hline Rotation I & Wheat & Soybean & Black oats & Maize & Wheat & Soybean \\
\hline Rotation II & Wheat & Soybean & Canola & Maize & Barley & Soybean \\
\hline Rotation III & Black oats + Rye + Vetch & $\begin{array}{l}\text { Bean/ } \\
\text { Sorghum }\end{array}$ & $\begin{array}{l}\text { Black oats+ } \\
\text { Vetch+Turnip }\end{array}$ & Maize & $\begin{array}{l}\text { Black oats + } \\
\text { Triticale + Rye }\end{array}$ & Soybean \\
\hline Rtation IV & Blue lupine + Black oats & Maize & White oats & $\begin{array}{l}\text { Bean/ } \\
\text { Turnip }\end{array}$ & Triticale & Soybean \\
\hline Rotation V & Black oats + Ryegrass & Soybean & $\begin{array}{c}\text { Black oats + } \\
\text { Ryegrass }\end{array}$ & Maize & $\begin{array}{c}\text { Black oats + } \\
\text { Ryegrass }\end{array}$ & Soybean \\
\hline
\end{tabular}

*Succession: crops succession, Rotation I: farmer crops rotation, Rotation II: cash crops rotation, Rotation III: phytomass crops rotation, Rotation IV: cash and phytomass crops rotation and Rotation V: consortium of Poaceae in the winter.

For determination of soil aggregate classes, in 2017 May, soil samples were collected at layers 0-5, 510 and $10-20 \mathrm{~cm}$, which, while still in the field, were passed in a $19 \mathrm{~mm}$ mesh sieve, in order to establish a maximum diameter for the aggregates, following the methodology described by Madari [15].

The distribution of aggregate classes was performed by wet sieving method described by Yoder [16], adapted by Castro Filho and coauthors [17], using mesh sieves of 8, 4, 2, 1 and $0.5 \mathrm{~mm}$ of diameter. From the aggregate classes, the Geometric Mean Diameter (GMD), Weighted Mean Diameter (WMD) and soil Aggregates Stability Index (ASI) were calculated according to equations 1, 2 and 3: 


$$
\begin{aligned}
& \text { GMD }=\operatorname{Exp} \frac{\sum_{i=1}^{n} \text { wp*logxi }}{\sum_{i=1}^{n} x i} \\
& \text { WMD }=\sum_{i=1}^{n}\left(\mathrm{xi}^{*} w i\right) \\
& \text { ASI }=\left(\frac{\text { dry sample wheight - wp50 - sand }}{\text { dry sample wheight - sand }}\right){ }^{*} 100
\end{aligned}
$$

Where: wi $=$ proportion of each class of aggregates in relation to the total; $w p=$ weight of aggregates of each class $(\mathrm{g}) ; \mathrm{xi}=$ mean diameter of the classes $(\mathrm{mm})$; wp50 = weight of aggregates of class $<0.5 \mathrm{~mm}$.

In each aggregate class the carbon content $(\mathrm{C})$ was determined by wet oxidation according to method described by Walkley [18], modified by Nelson [19].

The obtained results were submitted to the analysis of variance (ANOVA), applying the F test to identify the differences among the treatments, using the AgroEstat software [20]. For significant effects, means were compared by Tukey test at $5 \%$ probability $(p<0.05)$.

\section{RESULTS}

\section{Soil aggregation indexes}

There was no difference among crop rotations in each aggregate class and layers considered (Table 2). Comparing the aggregate classes in each crop rotation alone, there was a higher percentage of aggregates in the classes $<0.5 \mathrm{~mm}$ and $19-8 \mathrm{~mm}$ in the 0 to $5 \mathrm{~cm}$ layer, with no statistical difference between these two classes. In the other layers, the highest percentage of aggregates was for the class $<0.5 \mathrm{~mm}$, followed by $19-8$ and $8-4 \mathrm{~mm}$. It was also observed that macro-aggregates $(>2 \mathrm{~mm})$ decreased in depth and microaggregates increased. 
Table 2. Soil aggregate classes in crop rotations under no-tillage system at the layers: 0 to 5,5 to 10 and 10 to $20 \mathrm{~cm}$

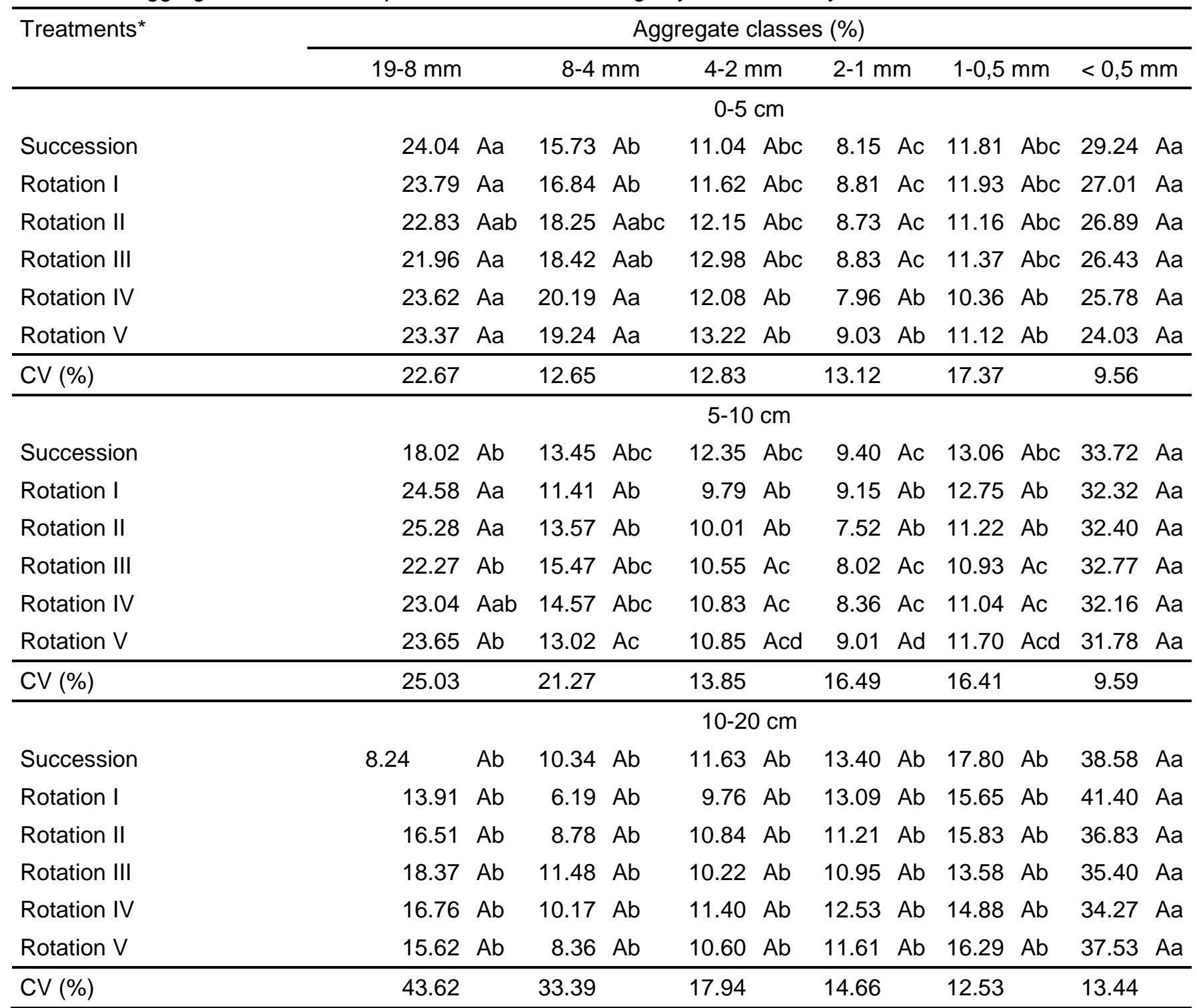

*Succession: crops succession, Rotation I: farmer crops rotation, Rotation II: cash crops rotation, Rotation III: phytomass crops rotation, Rotation IV: cash and phytomass crops rotation and Rotation V: consortium of Poaceae in the winter. Means followed by same lowercase letters in the column and same uppercase letters in the row in each soil layer do not differ by the Tukey test at $5 \%$ probability. CV: coefficient of variation.

The soil macro-aggregation (>2 $\mathrm{mm}$ ) in the superficial layer was significantly higher when compared to the other soil layers (Figure 1). This is due to the continuous input of plant residues through crop rotations under no-till, that promote increment of organic matter, with consequent response in the formation of larger and more stable aggregates. On the other hand, the soil micro-aggregation $(<2 \mathrm{~mm})$ was significantly higher in the $10-20 \mathrm{~cm}$ layer when compared to the others. 


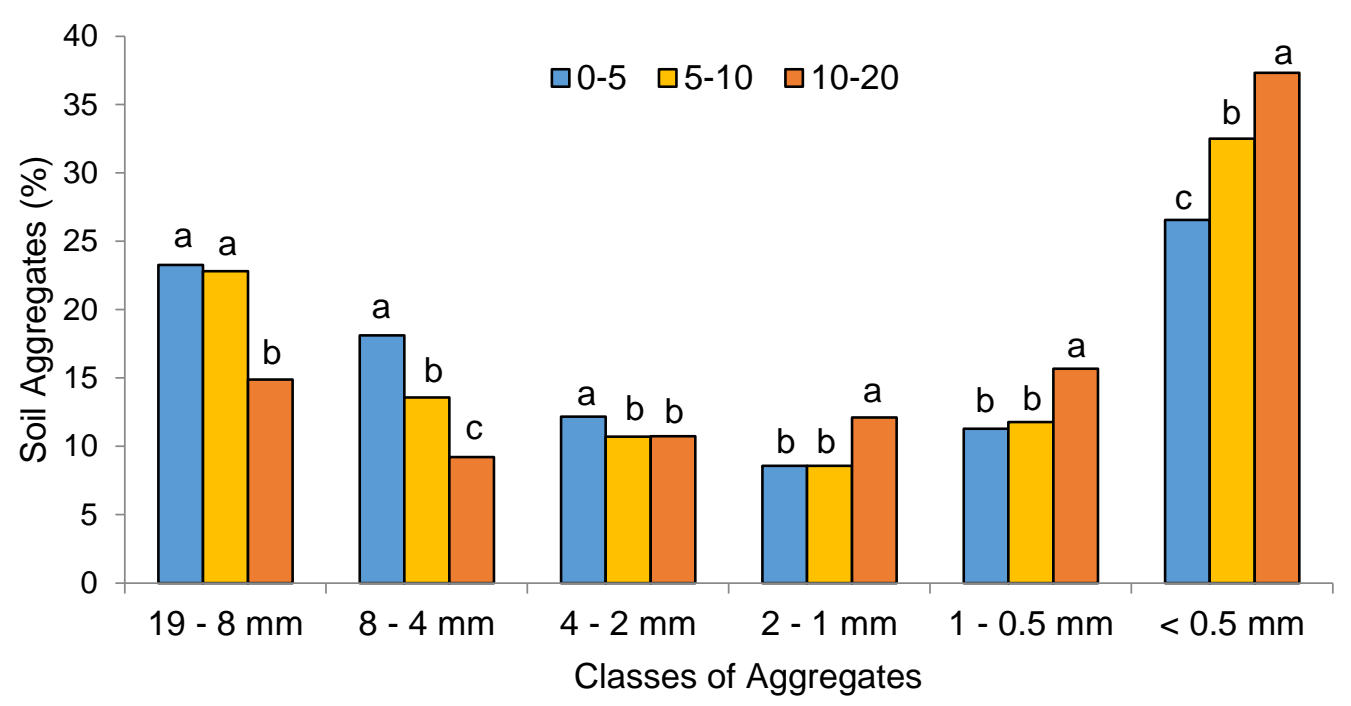

Figure 1. Distribution of Soil aggregates $(\%)$ in each class $(8,4,2,1,0.5$ and less than $0.5 \mathrm{~mm})$ in the soil layers: 0 to 5,5 to 10,10 to $20 \mathrm{~cm}$

Figure 2 shows the results obtained for soil aggregation indexes. In the soil surface layer, from 0 to $5 \mathrm{~cm}$ depth, there was great uniformity in WMD and GMD values among crop rotations, not differing statistically. Although not significant, ASI was lower in the crops succession and higher in the rotation $\mathrm{V}$ compared to other treatments (Figure 2a). Probably, this result is due to the dense root system of the black oats + ryegrass consortium, growing in the winter, which species have been indicated as benefic to the soil quality, improving aggregates stability.

In the 5 to $10 \mathrm{~cm}$ layer, WMD, GMD and ASI did not differ among the crop rotations (Figure 2b), but there was a decrease in all soil aggregation indexes with the depth increase. Also in this layer, although not significant, the rotation $\mathrm{V}$ and crops succession presented, respectively, the highest and lowest value for ASI.

In the 10 to $20 \mathrm{~cm}$ layer there was no difference among crop rotations for WMD, GMD and ASI (Figure 2c). In this layer, different of the others, the highest absolute value for ASI was in rotation IV and the lowest in the rotation I. 

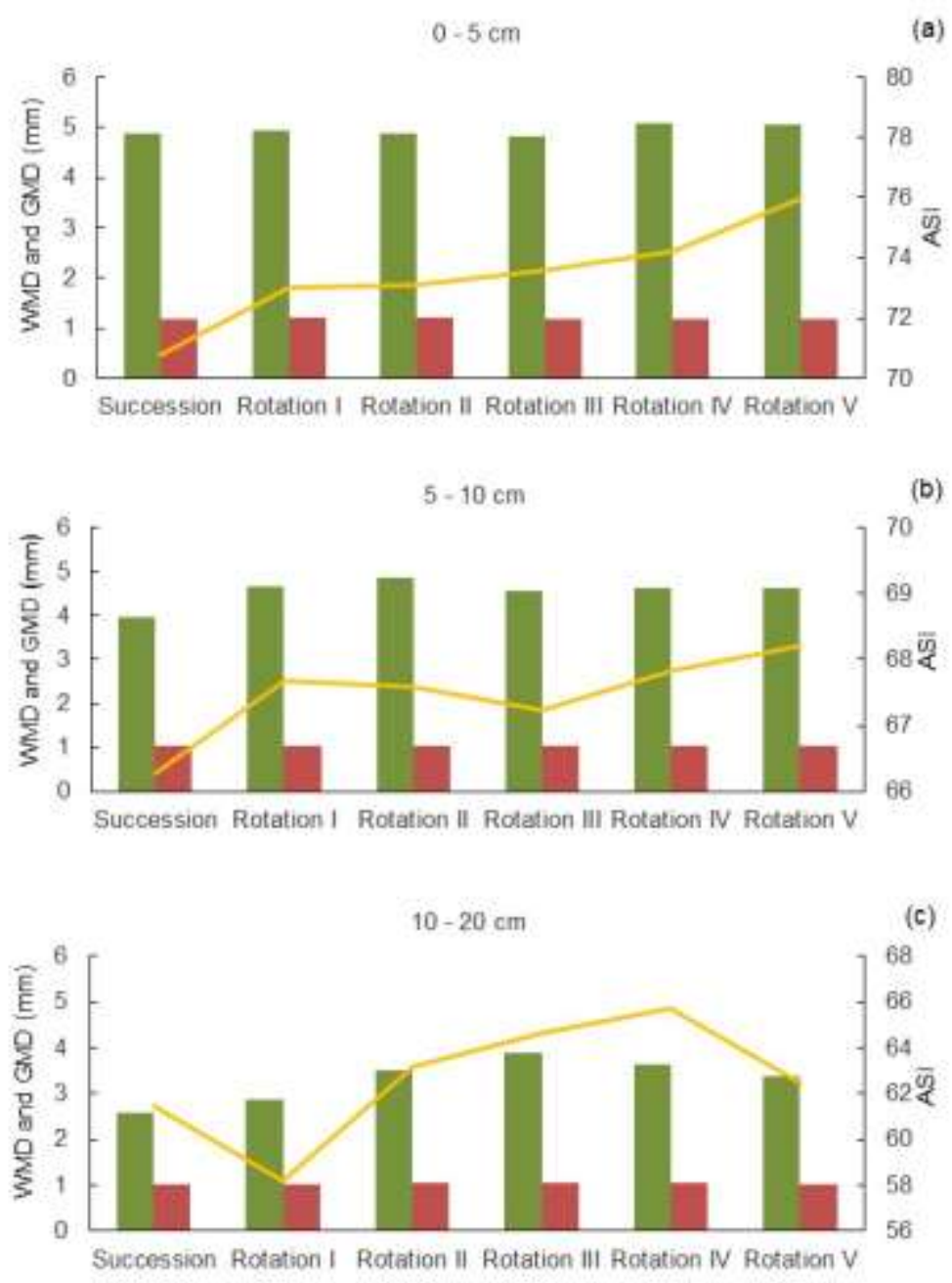

$=$ WMD $=$ GMD $\longrightarrow$ ASI

Figure 2. Comparison between crop rotations for soil aggregation indexes, weighted mean diameter (WMD), geometric mean diameter (GMD) and aggregation stability index (ASI) at the soil layers: a) 0 to $5 \mathrm{~cm}$, b) 5 to $10 \mathrm{~cm} \mathrm{c)} 10$ to $20 \mathrm{~cm}$. Treatments - Succession: crops succession, Rotation I: farmer crops rotation, Rotation II: cash crops rotation, Rotation III: phytomass crops rotation, Rotation IV: cash and phytomass crops rotation and Rotation V: consortium of Poaceae in the winter.

Soil aggregation indexes decreased with increasing soil depth (Table 3). The continuous input of vegetal residues by crop rotations under no-tillage system contribute to the increase of organic matter, resulting in the improvement of the soil aggregation indexes, being this effect more pronounced in the soil surface layer, indicating, however, that is necessary more time to reach greater depths.

Table 3. Behavior of soil aggregation indexes, weighted mean diameter (WMD), geometric mean diameter (GMD) and aggregates stability index (ASI) in the soil layers

\begin{tabular}{lrrr}
\hline Layer & \multicolumn{4}{c}{ soil aggregation indexes } \\
\cline { 2 - 4 } & WMD $(\mathrm{mm})$ & $\mathrm{GMD}(\mathrm{mm})$ & ASI $(\%)$ \\
\hline $0-5 \mathrm{~cm}$ & $4.94 \mathrm{a}$ & $1.19 \mathrm{a}$ & $73.44 \mathrm{a}$ \\
$5-10 \mathrm{~cm}$ & $4.55 \mathrm{a}$ & $1.05 \mathrm{~b}$ & $67.47 \mathrm{~b}$ \\
$10-20 \mathrm{~cm}$ & $3.30 \mathrm{~b}$ & $1.02 \mathrm{c}$ & $62.59 \mathrm{c}$ \\
$\mathrm{CV} \%$ & 7.98 & 0.74 & 2.74
\end{tabular}

Means followed by the same letter in the column do not differ by the Tukey test at $5 \%$ probability. 


\section{Carbon content in soil aggregates}

Carbon content did not differ among crop rotations, regardless of the aggregate classes and soil layers (Table 4). This result is probably due to the short time since the implementation of the field experiment, only three years, which was not enough for significant changes. No-tillage associated with crop rotation is a conservationist system that brings long-term benefits, requiring, however, longer time to show significant changes.

Table 4.Comparison among crop rotations for carbon content in the aggregate classes and soil layers

\begin{tabular}{|c|c|c|c|c|c|c|c|}
\hline \multirow[t]{3}{*}{ Treatments* } & \multicolumn{7}{|c|}{ Carbon content $\left(\mathrm{g} / \mathrm{dm}^{3}\right)$} \\
\hline & \multicolumn{7}{|c|}{ Classes of Aggregates } \\
\hline & $19-8 \mathrm{~mm}$ & \multicolumn{2}{|c|}{$8-4 \mathrm{~mm}$} & \multirow{2}{*}{$\frac{4-2 \mathrm{~mm}}{0-5 \mathrm{~cm}}$} & \multicolumn{2}{|c|}{ 2-1 mm } & $1-0.5 \mathrm{~mm}$ \\
\hline & & & & & & & \\
\hline Succession & $21.04 \mathrm{a}$ & 23.77 & $\mathrm{a}$ & $25.71 \mathrm{a}$ & 22.40 & $\mathrm{a}$ & 21.33 \\
\hline Rotation I & $21.33 \mathrm{a}$ & 22.99 & $\mathrm{a}$ & $24.45 \mathrm{a}$ & 25.23 & $\mathrm{a}$ & 23.47 a \\
\hline Rotation II & $22.21 \mathrm{a}$ & 25.81 & $\mathrm{a}$ & $23.28 \mathrm{a}$ & 22.50 & $\mathrm{a}$ & 22.89 a \\
\hline Rotation III & $21.72 \mathrm{a}$ & 26.20 & $\mathrm{a}$ & $24.35 \mathrm{a}$ & 26.10 & $\mathrm{a}$ & 24.06 a \\
\hline Rotation IV & $22.60 \mathrm{a}$ & 31.13 & $\mathrm{a}$ & $22.30 \mathrm{a}$ & 23.57 & $\mathrm{a}$ & 22.79 a \\
\hline Rotation V & $21.82 \mathrm{a}$ & 28.93 & $\mathrm{a}$ & $21.33 \mathrm{a}$ & 21.92 & $\mathrm{a}$ & 21.92 \\
\hline \multirow[t]{2}{*}{ CV (\%) } & 13.78 & 15.67 & & 17.83 & 16.10 & & 12.36 \\
\hline & \multicolumn{7}{|c|}{$5-10 \mathrm{~cm}$} \\
\hline Succession & $18.70 \mathrm{a}$ & 23.31 & $\mathrm{a}$ & $18.31 \mathrm{a}$ & 15.68 & $\mathrm{a}$ & 17.14 a \\
\hline Rotation I & $21.14 \mathrm{a}$ & 22.08 & $\mathrm{a}$ & $19.38 \mathrm{a}$ & 16.75 & $\mathrm{a}$ & 17.82 \\
\hline Rotation II & $18.21 \mathrm{a}$ & 19.62 & $a$ & $22.40 \mathrm{a}$ & 16.56 & $\mathrm{a}$ & 18.31 a \\
\hline Rotation III & $16.46 \mathrm{a}$ & 18.80 & $a$ & $16.95 \mathrm{a}$ & 18.31 & $a$ & 15.68 \\
\hline Rotation IV & $18.70 \mathrm{a}$ & 22.32 & $a$ & $18.51 \mathrm{a}$ & 17.92 & $a$ & 18.51 \\
\hline Rotation V & $19.77 \mathrm{a}$ & 19.97 & $\mathrm{a}$ & $17.53 \mathrm{a}$ & 18.51 & $a$ & 16.27 \\
\hline \multirow[t]{2}{*}{ CV (\%) } & 12.14 & 15.06 & & 17.35 & 9.53 & & 9.63 \\
\hline & \multicolumn{7}{|c|}{$10-20 \mathrm{~cm}$} \\
\hline Succession & $14.71 \mathrm{a}$ & 19.38 & $a$ & $16.56 \mathrm{a}$ & 16.17 & $a$ & 15.49 a \\
\hline Rotation I & $15.97 \mathrm{a}$ & 21.25 & $a$ & $18.21 \mathrm{a}$ & 15.39 & $a$ & 17.05 \\
\hline Rotation II & $15.19 \mathrm{a}$ & 17.34 & $a$ & $18.21 \mathrm{a}$ & 16.17 & $a$ & 15.97 \\
\hline Rotation III & $14.12 \mathrm{a}$ & 17.73 & $a$ & 19.48 a & 16.17 & $a$ & 15.78 \\
\hline Rotation IV & $15.49 \mathrm{a}$ & 18.65 & $a$ & $21.53 \mathrm{a}$ & 15.29 & $a$ & 15.88 \\
\hline Rotation V & $17.34 \mathrm{a}$ & 19.09 & $a$ & $19.38 \quad \mathrm{a}$ & 17.92 & $a$ & 15.78 \\
\hline CV (\%) & 14.27 & 14.29 & & 26.14 & 11.92 & & 11.15 \\
\hline
\end{tabular}

*Succession: crops succession, Rotation I: farmer crops rotation, Rotation II: cash crops rotation, Rotation III: phytomass crops rotation, Rotation IV: cash and phytomass crops rotation and Rotation V: consortium of Poaceae in the winter. Means followed by the same letter in the column at each depth do not differ from each other by the Tukey test at $5 \%$ probability.

Although the $\mathrm{C}$ content in the aggregate classes showed no differences among crop rotations at each depth, when analyzing the carbon content among the soil layers, regardless of the crop rotation, higher $\mathrm{C}$ levels were observed in the surface layer, decreasing with the depth. This effect was observed for all classes of aggregates, indicating carbon stratification among the soil layers (Figure 3 ). 
$\square 0-5 \mathrm{~cm} \quad \square 5-10 \mathrm{~cm} \quad \square 10-20 \mathrm{~cm}$

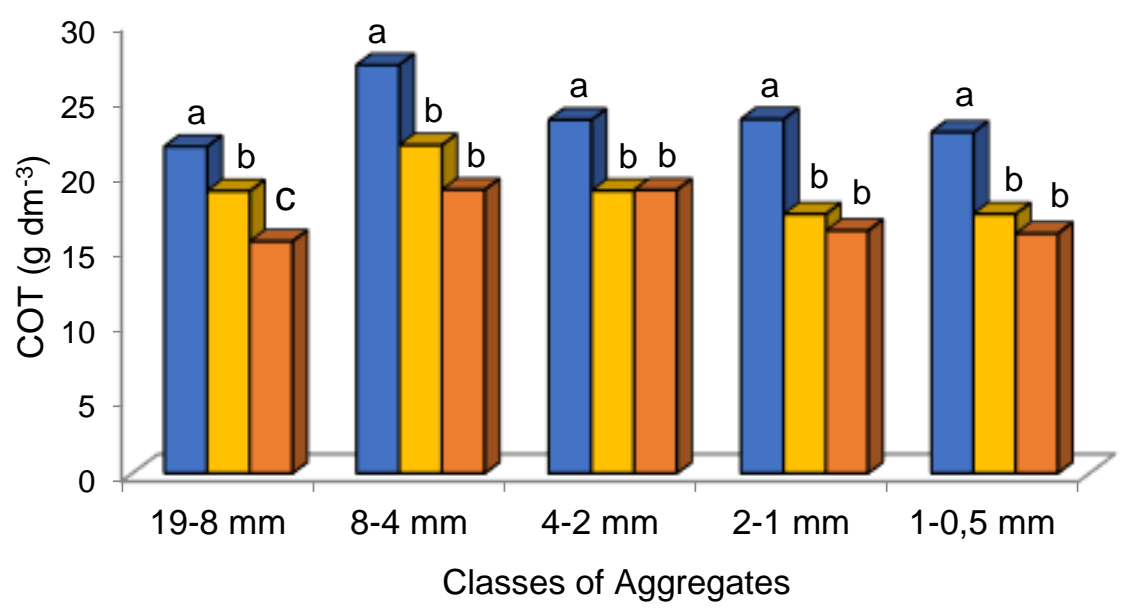

Figure 3. Organic carbon content in each aggregate class in the layers: 0 to 5,5 to 10,10 to $20 \mathrm{~cm}$

\section{DISCUSSION}

\section{Soil aggregation indexes}

Although the aggregate classes had not been affected by crop rotations, they were all larger in soil surface and decreased in depth. According to Canalli [21] this effect is due to the action of the roots and the contribution of organic material by the different soil coverings, providing soil protection against disintegration caused by sudden changes in humidity and the impact of rainfall, as well as increasing microbial activity, producing substances that aid in the formation and stabilization of aggregates.

Corroborating, Garcia and Rosolem [22] showed better soil structure restricted to the layer between 0 and $5 \mathrm{~cm}$ depth after the first year of cultivation of different cover crops, with increase of the WMD and in the proportion of aggregates larger than $2 \mathrm{~mm}$. According to the authors, this short-term effect was the result of higher shoot production and dense root system of the sorghum and pearl millet. The high root density acts physically in the formation and stabilization of macroaggregates, besides adding $C$ to the soil [8].

However, this effect is not easily observed in a short time of cover crops and crop rotation systems adoption, as reported by Coutinho and coauthors [23], in a similar study, where observed no significant differences between the different cropping systems in the soil aggregation indicators in a short period (two years). However when evaluated after eight years of implantation, significantly higher values of WMD and GMD were observed for maize + brachiaria when compared to maize + crotalaria, showing that a longer management time under no-tillage system with different crops rotation tends to influence directly in the soil aggregation. The authors highlighted that this result may be due to the higher organic matter content generated by the crops rotation, favoring the formation of larger and more stable aggregates.

Similar result was observed by Torres and coauthors [7], who compared the soil aggregate stability indexes in areas without vegetation cover and the same area after 12 years of no-tillage system implementation, using different soil cover plants for phytomass production. In this case, the authors showed that there was soil restructuring and system stabilization, presenting significantly higher aggregates stability indexes for all cover crops and sampling depths after a long period of system implantation. The Poaceae, among the cultivated plant species, are indicated to recover soil degradation, by presenting greater efficiency in the formation and stabilization of aggregates when compared to the Fabaceae, however, it is need a longer time under cultivation and management, so that structural benefits of the soil can be observed [24].

\section{Carbon content in soil aggregates}

Soil organic matter is the main agent of formation and stabilization of the soil aggregates, which is why evaluating organic matter and soil aggregation is so important. The increase of SOM is related to crops rotation and soil management. A evolution scale for no-tillage system was proposed by Sá and coauthors 
[25], establishing as initial phase the period comprising between zero to 5 years, characterized by the beginning of organic matter accumulation and soil structure recovering; in the transition phase, from 6 to 10 years, the carbon accumulation and the aggregates formation is already easily noted; in the consolidation phase, from 11 to 20 years, there is an effective increase of organic matter, promoting formation of larger and more stable aggregates, besides of other benefits for chemical and biology soil attributes, and finally, the maintenance phase, from 20 years on.

Corroborating, results obtained by Rosa and coauthors [26] show that, in the first year of evaluation, maize rotated cover crops did not influence the soil organic matter and organic carbon content, emphasizing that the organic carbon content gradually increases, showing improvements in soil quality over time. In the following year, after rotation involving cover crops and soybeans, it was possible to observe significant increases in organic carbon content and $25 \%$ increase in organic matter, due to the input of crop residues and cumulative effect of the crop rotation.

In a long-term study with different cover crops, Coutinho and coauthors [23] found a higher percentage of macroaggregates at all sampling depths, and higher carbon contents in the soil aggregate classes, with higher efficiency of Poaceae species, as a function of their root system when compared to Fabaceae species. The aggressive root system and the high Poaceae biomass production are characteristics of these species that contribute to the formation of soil aggregates [11] and to the increase of soil organic matter [9]. These results indicate that cover crops in the rotation systems, during the off season, are great alternatives that help increase the organic matter content and soil aggregation and, consequently, improve soil quality.

Quantifying organic carbon in areas under different soil management systems, Rossetti and coauthors [27] found higher C stocks in the superficial layer in No-Till system, and reported that this effect is a result of the superficial input of crop residues combined with the absence of soil mobilization in this system. These authors emphasize the importance of considering the duration of the no-tillage system in the efficiency of soil $\mathrm{C}$ increase. Evaluating the variation of the carbon stratification ratio in soil aggregates managed in No-Till, Ferreira and coauthors [10] verified a great increment of $C$ in the superficial layers in relation to the subsurface layers, confirming a stratification relationship in the soil profile and, emphasizing that this index can be used as an indicator of soil quality.

The results of the present study, in relation to soil carbon content and its consequent contribution to the formation of larger and more stable soil aggregates, indicate that are needed evaluations of more long-term in order to crop rotations under no-tillage can showing some difference in carbon content and soil structural quality.

\section{CONCLUSIONS}

Crop rotations did not influence the distribution of aggregate classes and soil aggregation indexes: Geometric Mean Diameter, Weighted Mean Diameter and soil Aggregates Stability Index at each soil layer.

Carbon content in the soil aggregates classes did not differ among crop rotations at each soil layer.

Aggregation indexes and soil organic carbon content decreased with depth, indicating a carbon stratification relationship in the soil profile.

The no effect of the crop rotations on the soil carbon and aggregation, in a cycle of just three-year, indicates that studies of more long-term are needed in order to observe possible changes in these soil attributes.

\section{REFERENCES}

1. Andrade RS, Stone LF, Silveira PM. Culturas de cobertura e qualidade física de um Latossolo em plantio direto [Cover crops and physical quality of a Latosol under no-tillage]. R. Bras. Eng. Agric. Ambiental. 2009;13(4):411-8.

2. Souza LCF, Luís AJ, Piletti LMMS. Características agronômicas do milho em função da cultura antecessora em sistema plantio direto [Agronomic characteristics of corn as a function of the precursor crop under no-tillage]. R. Bras. Milho e Sorgo. 2016; 15(2): 272-80.

3. Amaral CB, Pinto CC, Flôres JA, Mingotte FLC, Lemos LB, Fornasieri Filho D. Produtividade e qualidade do feijoeiro cultivado sobre palhadas de gramíneas e adubado com nitrogênio em plantio direto [Productivity and quality of common bean cultivated on grass straws and fertilized with nitrogen under no-tillage]. Pesq. Agropec. Bras. 2016;51(9):1602-9.

4. Freitas LA, Mello LMM, Andreotti M, Yano EH, Soares DA, Pereira DS. Soil physical and phenological attributes of soybean in different management systems and gypsum. Rev.Bras. Cienc. Agrar. 2017;12(4):508-15. 
5. Caires EF, Milla R. Adubação nitrogenada em cobertura para o cultivo de milho com alto potencial produtivo em sistema de plantio direto de longa duração [Nitrogen fertilization in top dressing for corn crop with high yield potential under a long-term no-till system]. Bragantia. 2017;75(1):87-95.

6. Nouwakpo SK, Song J, Gonzalez JM. Soil structural stability assessment with the fluidized bed, aggregate stability and rainfall simulation on long-term tillage and crop rotation systems. Soil Till Res. 2018;178:65-71.

7. Torres JLR, Pereira MG, Assis RL, Souza ZM. Atributos físicos de um Latossolo vermelho cultivado com plantas de cobertura, em semeadura direta [Physical attributes of a Red Latosol cultivated with cover crops under no-tillage system]. R. Bras.Ci. Solo. 2015;39(2):428-37.

8. Vezzani FM, Mielniczuk J. Agregação e estoque de carbono em argissolo submetido a diferentes práticas de manejo agrícola [Aggregation and carbono stock in a Paleudult submitted to diferent agricultural managements]. R. Bras.Ci. Solo. 2011;35(1):213-23.

9. Seidel EP, Gerhardt IFS, Castagnara DD, Neres MA. Efeito da época e sistema de semeadura da Brachiaria brizantha em consórcio com o milho, sobre os componentes de produção e propriedades físicas do solo [Effect of season and sowing system of Brachiaria brizantha intercropped with mayse on yield components and soil physical properties]. Semina: Cienc. Agrar. 2014;35(1):55-66.

10. Ferreira AO, Sá JCM, Harms MG, Miara S, Briedis C, Quadros Netto C, Burkner JS, Canalli LBS, Dias CTS. Relação de estratificação como indicador do sequestro de carbono em macroagregados de um Latossolo sob plantio direto [Stratification ratio as soil carbon sequestration indicator in macroaggregates of Oxisol under notillage]. Cienc. Rural. 2012;42(4):645-52.

11. Borges CS, Ribeiro BT, Wendling $B$, Cabral DA. Agregação do solo, carbono orgânico e emissão de $\mathrm{CO}_{2}$ em áreas sob diferentes usos no Cerrado, região do Triângulo Mineiro [Soil aggregation, organic carbon and $\mathrm{CO}_{2}$ emission in different land uses in Brazilian Savanna, Triangulo Mineiro region]. Rev. Ambient. Água. 2015;10(3):660-75.

12. Portugal AF, Juncksh I, Schaefer CERG, Neves JCL. Estabilidade de agregados em argissolo sob diferentes usos, comparado com mata [Aggregate stability in an ultisol under different uses, compared to forest]. Rev. Ceres. 2010; 57(4): 545-53.

13. Embrapa - Empresa Brasileira de Pesquisa Agropecuária. Sistema Brasileiro de Classificação de Solos [Brazilian system of soil classification]. 3rd ed., rev. ampl. Rio de Janeiro, Brazil: Embrapa; 2013. 353 p.

14. Iapar. Médias climáticas históricas em Estações Meteorológicas do IAPAR [Historical climate averages at IAPAR Meteorological Station]. Available online at: http://www.iapar.br (accessed on: Fev. 28, 2020).

15. Madari BE. Fracionamento de agregados: Procedimento para uma estimativa compartimentada do sequestro de carbono no solo [Aggregates fractionation: Procedure for a compartmentalized estimate of soil carbon sequestration]. Comunicado Técnico n.22. Embrapa: Rio de Janeiro, Brasil; 2004. 10 p.

16. Yoder RE. A direct method of aggregate analysis of soils and a study of the physical nature of erosion losses. Agron. J.1936; 28(5): 337-51.

17. Castro Filho C, Muzilli O, Podanoschi AL. Estabilidade dos agregados e sua relação com o teor de carbono orgânico num Latossolo roxo distrófico, em função de sistemas de plantio, rotações de culturas e métodos de preparo das amostras [Soil aggregates stability and its relation with organic carbon in a Typic Haplorthox as a function of tillage systems, crop rotations and soil sample preparation]. Rev. Bras. Ciên. Solo. 1998; 22(3): 527-38.

18. Walkley A, Black IA. An Examination of the Degtjareff Method for Determining Soil Organic Matter and a Proposed Modification of the Chromic Acid Titration Method. Soil Science. 1934; 37(1): 29-38.

19. Nelson DW, Sommers LE. Total Carbon, Organic Carbon and Organic Matter. In: Methods of Soil Analysis, Part 2. Chemical and Microbiological Properties, 2nd ed.; Page AL, Ed.; Soil Sci. Soc. Am.: Madison, USA, 1996; pp. 9631010.

20. Barbosa JC, Maldonado Júnior W. Software Agro Estat: Sistema de análises estatísticas de ensaios agronômicos [System for statistical Analysis of agronomic trials]. Universidade Estadual Paulista: Jaboticabal, Brazil, 2012.

21. Canalli LBS. Decomposição de resíduos culturais e sua contribuição nos macroagregados e na fração lábil da matéria orgânica do solo no sistema plantio direto [Crop residues decomposition and its contribution for macroaggregates and labile soil organic matter under no-tillage] [PhD thesis]. Curitiba-PR (Brazil): Universidade Federal do Paraná, Doutorado em Agronomia; 2009. 101 p.

22. Garcia RA, Rosolem CA. Agregados em um Latossolo sob sistema plantio direto e rotação de culturas [Aggregates in a Rhodic Ferralsol under no-tillage and crops rotation]. Pesq. Agropec. Bras. 2010;45(12):1489-98.

23. Coutinho FS, Loss A, Pereira MG, Rodrigues Junior DJ, Torres JLR. Estabilidade de agregados e distribuição do carbono em Latossolo sob sistema plantio direto em Uberaba, M.G [Aggregate stability and carbon distribution in Oxisol under no-tillage system in Uberaba, Minas Gerais State, Brazil]. Comum. Sci. 2010;1(2):100-5. 
24. Wendling B, Kucksch I, Mendonça ES, Neves JCL. Carbono orgânico e estabilidade de agregados de um Latossolo Vermelho sob diferentes manejos [Organic carbon and aggregate stability of a Red Latossol under different managements]. Pesq. Agropec. Bras. 2005; 40(5): 487-94.

25. Sá JCM, Cerri CC, Piccolo MC, Feigl BE, Buckner J, Seguy L, Bouzinac S, Venzke Filho SP, Paulleti V, Siqueira Neto M. O plantio direto como base do sistema de produção visando o sequestro de carbono [No-tillage as a base of the production system aiming carbon sequestration]. Rev. Plantio Direto. 2004; 84: 45-62.

26. Rosa DM, Nóbrega LHP, Mauli MM, Lima GP, Pacheco FP. Substâncias húmicas do solo cultivado com plantas de cobertura em rotação com milho e soja [Humic substances in soil cultivated with cover crops rotated with maize and soybean]. Rev. Ciênc. Agron. 2017; 48(2): 221-30.

27. Rossetti KV, Centurion JF. Estoque de carbono e atributos físicos de um Latossolo em cronossequência sob diferentes manejos [Carbon stock and physical attributes of an Oxisol in chronosequence under different managements practices]. Rev. Bras. Eng. Agric. Ambiental. 2015;19(3):252-8.

2020 by the authors. Submitted for possible open access publication under the terms and conditions of the Creative Commons Attribution (CC BY NC) license (https://creativecommons.org/licenses/by-nc/4.0/). 